Наносистели, нанолатеріали, нанотехнології Nanosistemi, Nanomateriali, Nanotehnologii 2019 , т. 17 , № 3, сc. 483-490 (c) 2019 IMФ (Інститут металофізики ім. Г. В. Курдюмова НАН України) Надруковано в Україні. Фотокопіювання дозволено тільки відповідно до ліцензі

PACSnumbers: 61.72.jd, 68.55.J-, 73.50.Pz, 73.61.Ng, 78.55.-m, 81.15.Gh, 81.40.Tv

\title{
Influence of the Obtaining Conditions on the Photoconductivity of Thin $\beta-\mathrm{Ga}_{2} \mathrm{O}_{3}$ Films
}

O. M. Bordun ${ }^{1}$, B. O. Bordun ${ }^{1}$, I. Yo. Kukharskyy ${ }^{1}$, I. I. Medvid ${ }^{1}$, I. S. Zvizlo ${ }^{1}$, and D. S. Leonov ${ }^{2}$

\author{
${ }^{1}$ Ivan Franko National University of Lviv, \\ 50, Drahomanov Str., \\ UA-79005 Lviv, Ukraine \\ ${ }^{2}$ Technical Centre, N.A.S. of Ukraine, \\ 13, Pokrovska Str., \\ UA-04070 Kyiv, Ukraine
}

The photoconductivity of thin $\beta-\mathrm{Ga}_{2} \mathrm{O}_{3}$ films obtained by radio-frequency (RF) ion-plasma sputtering, depending on the conditions of obtaining, is investigated. As established, the highest value of photoconductivity current is observed in freshly deposited films and decreases when films are reduced in a hydrogen atmosphere, at annealing in an argon atmosphere and especially in an oxygen atmosphere. The analysis of spectral shift of the photoconductivity maximum of the excitation spectrum via the heat treatment atmosphere is carried out.

Досліджено фотопровідність тонких плівок $\beta-\mathrm{Ga}_{2} \mathrm{O}_{3}$, одержаних методою високочастотного йонно-плазмового розпорошення, залежно від умов одержання. Встановлено, що найбільша величина струму фотопровідности спостерігається у свіжонанесених плівках і зменшується при відновленні плівок в атмосфері водню, при відпалі в атмосфері аргону і особливо кисню. Проведено аналізу спектрального зміщення максимуму спектру збудження фотопровідности залежно від атмосфери термооброблення.

Исследована фотопроводимость тонких плёнок $\beta-\mathrm{Ga}_{2} \mathrm{O}_{3}$, полученных методом высокочастотного ионно-плазменного распыления, в зависимости от условий получения. Установлено, что наибольшая величина тока фотопроводимости наблюдается в свеженанесённых плёнках и уменьшается при восстановлении плёнок в атмосфере водорода, при отжиге в атмосфере аргона и особенно кислорода. Проведён анализ спектрального смещения максимума спектра возбуждения фотопроводимости в зависимости от атмосферы термообработки. 
Key words: gallium oxide, thin films, photoconductivity.

Ключові слова: оксид галію, тонкі плівки, фотопровідність.

Ключевые слова: оксид галлия, тонкие плёнки, фотопроводимость.

(Received 10 May, 2019)

\section{INTRODUCTION}

Recent studies have revealed a number of interesting properties of $\beta-\mathrm{Ga}_{2} \mathrm{O}_{3}$ films obtained by various methods. On this basis, the films based on $\beta-\mathrm{Ga}_{2} \mathrm{O}_{3}$ are widely used as thin-film materials for fieldeffect transistors (FET) [1], gas sensors [2], and electrodes, which are transparent in the UV region [3]. Depending on the method of obtaining and the dopant impurity, such films are used as photoluminophors $[4,5]$, cathodoluminophors and electroluminophors [6, $7]$. In the general case, the optical and electrical properties of $\beta$ $\mathrm{Ga}_{2} \mathrm{O}_{3}$ films are determined by the methods of obtaining, the modes of deposition and subsequent technological techniques as well as the introduction of impurities, which can controllably change the properties of thin films. One among the important tasks for expanding application of $\beta-\mathrm{Ga}_{2} \mathrm{O}_{3}$-based phosphors is to improve the conductivity of these materials. Several methods are used to change the conductivity of $\beta-\mathrm{Ga}_{2} \mathrm{O}_{3}$ films, one of which is annealing in different atmospheres at high temperatures; it is discussed in this work. We studied thin films of $\beta-\mathrm{Ga}_{2} \mathrm{O}_{3}$ obtained by radio-frequency (RF) ionplasma sputtering, which is optimal for obtaining of homogeneous semiconductor and dielectric films.

\section{EXPERIMENTAL}

The thin $\beta-\mathrm{Ga}_{2} \mathrm{O}_{3}$ films with thickness of $0.2-0.8 \mu \mathrm{m}$ were obtained by $\mathrm{RF}$ ion-plasma sputtering on the fused $\mathrm{v}-\mathrm{SiO}_{2}$ quartz substrates. After that, they were thermally treated in oxygen or argon atmosphere at $1000-1100^{\circ} \mathrm{C}$ and in hydrogen atmosphere at $600-650^{\circ} \mathrm{C}$. $\mathrm{X}$-ray diffraction studies have shown the presence of a polycrystalline structure, which differs depending on the method of thermal treatment of films. The characteristic diffraction patterns for $\beta$ $\mathrm{Ga}_{2} \mathrm{O}_{3}$ films annealed in different atmospheres are given elsewhere [8]. At annealing in oxygen atmosphere, the predominant orientation of films is observed in the (400), (002), (111) and (512) planes. At annealing in argon atmosphere, the orientation in the (400), (002), (111) and (512) planes is also dominant, however, there is a relative decrease in the orientation in the (400) plane, the increase 
in the (111) plane, and the growth of orientations in the (113) plane. For films annealed in hydrogen atmosphere, a weakly developed structure of the diffraction spectrum is observed, in which reflections from the (400), (002) and (512) planes are also predominant. The reflexes, which do not correspond to $\beta-\mathrm{Ga}_{2} \mathrm{O}_{3}$, are not found on the diffraction patterns; thus, the presence of other phases was not detected.

The photoconductivity of $\beta-\mathrm{Ga}_{2} \mathrm{O}_{3}$ thin films with the change of the spectral composition of the exciting light with the support of a constant number of quanta falling on the film (isoquantum spectral sensitivity) was measured on an automated installation mounted on the base of $\mathrm{SF}-4 \mathrm{~A}$ spectrophotometer. The normalization in the spectral region of $3.5-5.6 \mathrm{eV}(350-220 \mathrm{~nm})$ was carried out by yellow luminogen, the quantum yield of luminescence of which does not depend on the energy of the exciting photons. An electrical voltage of 10-100 V was applied to two point contacts with a diameter of $1 \mathrm{~mm}$, which were spatially separated by $1 \mathrm{~mm}$. When measuring the current flowing in thin $\beta-\mathrm{Ga}_{2} \mathrm{O}_{3}$ films, the main requirement is the use of ohmic not rectifier contacts, which do not create additional barriers at the interface. Metals, whose work function is close to the electron affinity of the semiconductor, create the best ohmic contacts with semiconductors. We applied the silver paste with the work function of $\cong 4.3 \mathrm{eV}$. The electron affinity of $\beta-\mathrm{Ga}_{2} \mathrm{O}_{3}$ is of $4.0 \mathrm{eV}$ [9]. This type of contact material forms a conductor with a linear current-voltage characteristic [10], and many publications have reported about its use in the study of diamond, garnet and other high-resistance oxygen-containing samples [11-15]. The application of contacts on the surface of film allows recording the sum of the surface and bulk photocurrents simultaneously.

The spectra of the luminescence excitation in the spectral region of 220-300 nm (5.6-4.1 eV) were recorded on a Horiba Fluoromax$4 \mathrm{P}$ spectrophotometer.

\section{RESULTS AND DISCUSSION}

The studies have shown that photoconductivity effect is observed in $\beta-\mathrm{Ga}_{2} \mathrm{O}_{3}$ thin films, regardless of the composition of the heattreatment atmosphere. Figure 1 shows the characteristic photoconductivity spectra of the obtained films. The obtained spectra show that the smallest value of the photocurrent is observed in $\beta-\mathrm{Ga}_{2} \mathrm{O}_{3}$ films annealed in oxygen atmosphere, which contains the least amount of oxygen vacancies. The largest value of the photocurrent is characteristic of unannealed films with an incompletely shaped structure. As one can see in Fig. 1, two bands of photoconductivity are observed in the 220-270 $\mathrm{nm}$ spectral region and overlap each 


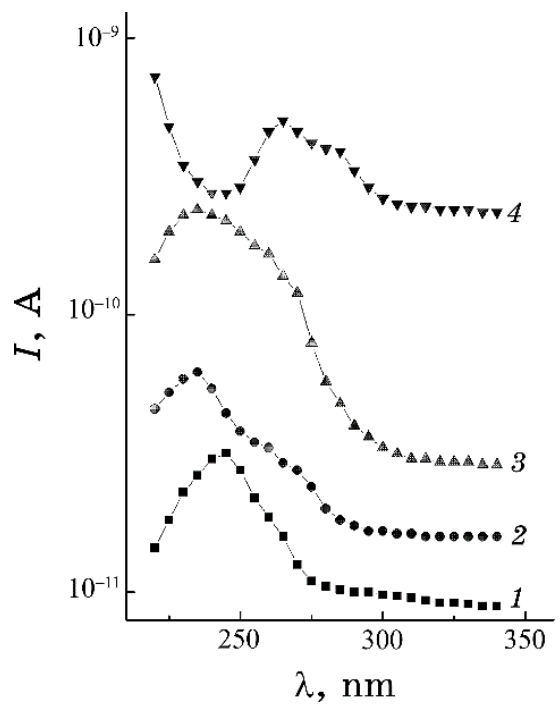

Fig. 1. Photoconductivity spectra of thin $\beta-\mathrm{Ga}_{2} \mathrm{O}_{3}$ films $(T=295 \mathrm{~K})$ after annealing in oxygen atmosphere (1), in argon atmosphere (2), and after reduction in hydrogen atmosphere pre-annealed in argon atmosphere (3) and unannealed thin films (4).

other in the photoconductivity spectra of annealed $\beta-\mathrm{Ga}_{2} \mathrm{O}_{3}$ films, regardless of the composition of the annealing atmosphere. The resulting spectrum forms the superposition of these bands.

It is well known that luminescence spectrum of $\beta-\mathrm{Ga}_{2} \mathrm{O}_{3}$ shows two characteristic emission bands in the ultraviolet (UV) region with a maximum at $397 \mathrm{~nm}$ and in the blue region with a maximum at $449 \mathrm{~nm}$ [16-18]. This is also confirmed by our studies of the stationary and thermally stimulated luminescence of thin $\beta-\mathrm{Ga}_{2} \mathrm{O}_{3}$ films $[19,20]$.

The characteristic excitation spectra of the UV and blue bands of luminescence in thin $\beta-\mathrm{Ga}_{2} \mathrm{O}_{3}$ films measured at $295 \mathrm{~K}$, at the temperature of the photoconductivity measurements, are shown in Fig. 2. As it can be seen from Fig. 2, regardless of the influence of thermal treatment of thin $\beta-\mathrm{Ga}_{2} \mathrm{O}_{3}$ films, the maximum of excitation band for the UV luminescence is located in the region of $245 \mathrm{~nm}$, and for the blue emission, in the region of $250 \mathrm{~nm}$. Considering the presence of spectral shift for the excitation maxima of these bands and the fact that they are excited almost in the same spectral region of 230-270 $\mathrm{nm}$, it can be assumed that the bands of the UV and blue luminescences in $\beta-\mathrm{Ga}_{2} \mathrm{O}_{3}$ films, most likely, have a different nature. At the same time, the luminescence centres responsible for these bands interact strongly enough with each other. These centres, according to [19], are most likely associated with singly 


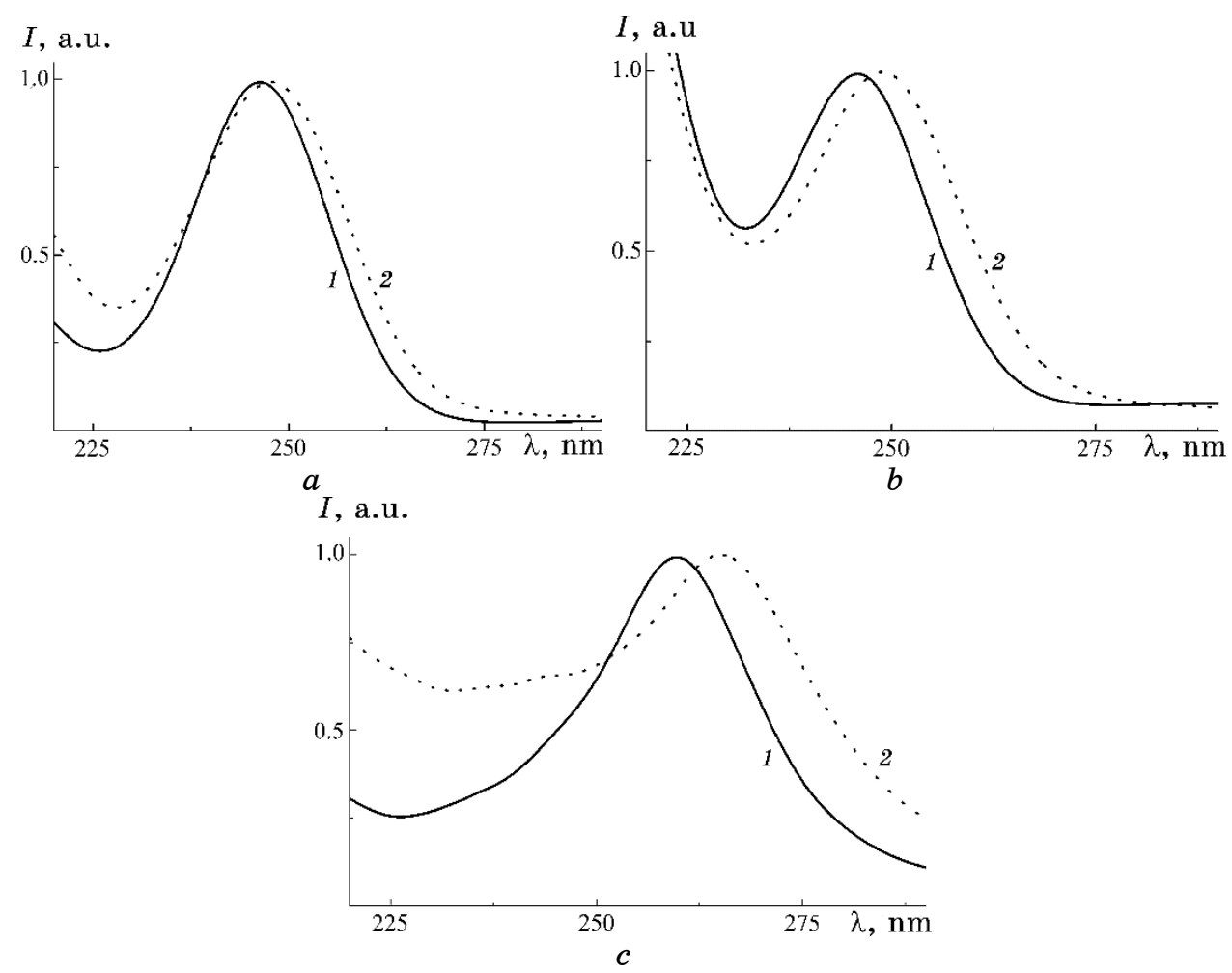

Fig. 2. The excitation spectra of luminescence for the UV band of luminescence with a maximum at $397 \mathrm{~nm}$ (1) and the blue band of luminescence with a maximum at $449 \mathrm{~nm}$ (2) for the annealed thin $\beta-\mathrm{Ga}_{2} \mathrm{O}_{3}$ films in the oxygen atmosphere $(a)$, the unannealed thin films $(b)$ and ceramics $(c)$; $T=295 \mathrm{~K}$.

charged associates of the vacancies of oxygen and gallium $\left(V_{\mathrm{O}}, V_{\mathrm{Ga}}\right)^{\prime}$. Two photoexcitation bands are well correlated with two photoconductivity ones, which form the total photoconductivity spectrum. It should also be noted that the photoconductivity spectrum of unannealed $\beta-\mathrm{Ga}_{2} \mathrm{O}_{3}$ films correlates well with the photoexcitation spectra of the UV and blue luminescence bands of $\beta-\mathrm{Ga}_{2} \mathrm{O}_{3}$ ceramics (Fig. 2, $c)$, which were used for thin $\beta-\mathrm{Ga}_{2} \mathrm{O}_{3}$ films' deposition.

Taking into account that the band gap of thin $\beta-\mathrm{Ga}_{2} \mathrm{O}_{3}$ films annealed, for example, in oxygen atmosphere is equal to $4.60 \mathrm{eV}$ (270 $\mathrm{nm})$ [21], the excitation of the luminescence and photoconductivity bands occurs in the region of the band-to-band transitions with the formation of free charge carriers in conduction band. This is the socalled own optical generation and, accordingly, intrinsic photoconductivity. According to the calculations of the electronic structure 
of $\beta-\mathrm{Ga}_{2} \mathrm{O}_{3}$ [22-24], such electronic transitions occur from the $2 p$ states of $\mathrm{O}$, which form the upper filled level of the valence band to the bottom of the conduction band formed by the hybridous $2 p$ states of $\mathrm{O}$ and $4 s$-states of Ga. The total energy required for such an electronic transition to a distance $r_{0}$, according to [25], is determined as

$$
H v=\varepsilon_{+}+\varepsilon_{-}-e^{2} / r_{0}+\chi\left(\mathrm{O}^{2-}\right)-I\left(\mathrm{Ga}^{2+}\right)-\psi_{\mathrm{pol}},
$$

where $\varepsilon_{+}$and $\varepsilon_{-}$are the values of the electrostatic energies of the gallium and oxygen sublattice, respectively, $\chi$ - the oxygen electron affinity, $I$-ionization potential of $\mathrm{Ga}^{2+}$, and $\psi_{\text {pol }}$ is the polarization energy of a dipole formed by charge transfer. According to this ratio, the most influence on change of the electronic-transition energy has $\psi_{\text {pol }}$, which, according to [25], can attain 1-2 eV. Taking into account that freshly deposited films are characterized by an incompletely formed structure and an increased number of oxygen vacancies, this can lead to a decrease in the value of electrostatic energy of the oxygen sublattice. In such deformed lattice, the average value of $r_{0}$ decreases and, accordingly, the component $e^{2} / r_{0}$ is increases, and the polarization energy of the dipole $\psi_{\text {pol }}$ is increased too. All these factors lead to a decrease in the energy of transition of the released electrons from the top of the valence band to the bottom of the conduction band in unannealed films. This is revealed out in the spectral shift of the photoconductivity excitation band maximum from $245 \mathrm{~nm}(5.05 \mathrm{eV})$ for $\beta-\mathrm{Ga}_{2} \mathrm{O}_{3}$ films, which were annealed in oxygen atmosphere to $270 \mathrm{~nm}(4.60 \mathrm{eV})$ for unannealed of $\beta-\mathrm{Ga}_{2} \mathrm{O}_{3}$ films.

Taking into account that, according to [21], the optical band gap $E_{g}$ of thin $\beta-\mathrm{Ga}_{2} \mathrm{O}_{3}$ films increases from $4.60 \mathrm{eV}(270 \mathrm{~nm})$ for films annealed in oxygen atmosphere, up to $4.65 \mathrm{eV}(267 \mathrm{~nm})$ for films annealed in argon atmosphere and to $5.20 \mathrm{eV}(240 \mathrm{~nm})$ after the reduction of annealed films in hydrogen atmosphere, this most likely results in the spectral shift of the photoconductivity maximum of thin $\beta-\mathrm{Ga}_{2} \mathrm{O}_{3}$ films after annealing in argon atmosphere and reduction in hydrogen atmosphere in the region of $235 \mathrm{~nm}(5.27 \mathrm{eV})$.

\section{CONCLUSION}

The carried out research show that the phenomenon of photoconductivity is observed in the $\beta-\mathrm{Ga}_{2} \mathrm{O}_{3}$ films obtained by $\mathrm{RF}$ ionplasma sputtering, regardless of the composition of the thermal treatment atmosphere. The most photocurrent value is observed in freshly deposited films, and the lowest is observed in $\beta-\mathrm{Ga}_{2} \mathrm{O}_{3}$ films, which are annealed in oxygen atmosphere. A comparison of the pho- 
toconductivity and the luminescence excitation spectra as well as the band gap shows that the photoconductivity in thin $\beta-\mathrm{Ga}_{2} \mathrm{O}_{3}$ films is due to band-band transitions with the formation of free charge carriers in the conduction band. The spectral shift of the maximum of the photoconductivity excitation spectrum depending on the conditions of obtaining is analysed.

\section{REFERENCES}

1. K. Matsuzaki, H. Yanagi, T. Kamiya, H. Hiramatsu, K. Nomura,

M. Hirano, and H. Hosono, Appl. Phys. Lett., 88, No. 9: 092106 (2006).

2. N. D. Cuong, Y. W. Park, and S. G. Yoon, Sensors and Actuators B, 140, No. 1: 240 (2009).

3. M. Orita, H. Ohta, M. Hirano, and H. Hosono, Appl. Phys. Lett., 77, No. 25: 4166 (2000).

4. J.-G. Zhao, Z.-X. Zhang, Z.-W. Ma, H.-G. Duan, X.-S. Guo, and E.-Q. Xie, Chinese Phys. Lett., 25, No. 10: 3787 (2008).

5. Y. Tokida and S. Adachi, Jpn. J. Appl. Phys., 52, No. 10R: 101102 (2013).

6. P. Wellenius, A. Suresh, J. V. Foreman, H. O. Everitt, and J. F. Muth, Mater. Sci. Eng. B, 146: 252 (2008).

7. T. Minami, T. Shirai, T. Nakatani, and T. Miyata, Jpn. J. Appl. Phys., 39, No. 6A: L524 (2000).

8. O. M. Bordun, I. Yo. Kukharskyy, B. O. Bordun, and V. B. Lushchanets, J. Appl. Spectrosc., 81, No. 5: 771 (2014).

9. S. J. Pearton, J. Yang, P. H. Cary IV, F. Ren, J. Kim, M. J. Tadjer, and M. A. Mastro, Appl. Phys. Rev., 5, No. 1: 011301 (2018).

10. I. B. Vendik, A. N. Ermolenko, V. V. Esipov, B. M. Pchelkin, and M. F. Sitnikova, Zhurn. Tekhn. Fiz., 58, No. 12: 2323 (1988) (in Russian).

11. W. Sinkler, L. D. Marks, D. D. Edwards, T. O. Mason, K. R. Poeppelmeier, Z. Hu, and J. D. Jorgensen, J. Solid State Chem., 136, No. 1: 145 (1998).

12. V. I. Vasyltsiv, Ya. I. Rym, and Ya. M. Zakharko, phys. status solidi (b), 195, No. 2: 653 (1996).

13. V. V. Tokii, V. I. Timchenko, and V. A. Soroka, Phys. of Sol. State, 45, No. 4: 600 (2003).

14. T. V. Blank and Yu. A. Gol'dberg, Semiconductors, 41, No. 11: 1281 (2007).

15. O. M. Bordun, V. G. Bihday, and I. Yo. Kukharskyy, J. Appl. Spectrosc., 80, No. 5: 721 (2013).

16. L. Binet and D. Gourier, J. Phys. Chem. Solids, 59, No. 8: 1241 (1998).

17. K. Shimamura, E. G. Víllora, T. Ujiie, and K. Aoki, Appl. Phys. Lett., 92, No. 20: 201914 (1) (2008).

18. G. Guzman-Navarro, M. Herrera-Zaldivar, J. Valenzuela-Benavides, and D. Maestre, J. Appl. Phys., 110, No. 3: 034315 (2011).

19. O. M. Bordun, B. O. Bordun, I. Yo. Kukharskyy, and I. I. Medvid, J. Appl. Spectrosc., 84, No. 1: 46 (2017).

20. O. M. Bordun, B. O. Bordun, I. I. Medvid, and I. Yo. Kukharskyy, Acta Physica Polonica, 134, No. 4: 910 (2018).

21. O. M. Bordun, I. Yo. Kukharskyy, B. O. Bordun, and V. B. Lushchanets, Phys. and Chem. of Sol. State, 16, No. 2: 302 (2015). 
22. S. K. Sampath and J. F. Cordaro, J. Am. Ceram. Soc., 81, No. 3: 649 (1998).

23. F. Litimein, D. Rached, R. Khenata, and H. Baltache, J. Alloys Comp., 488, No. 1: 148 (2009).

24. M. Michling and D. Schmeißer, IOP Conf. Ser.: Mater. Sci. Eng., 34: 012002 (2012).

25. H. H. Tippins, Phys. Rev., 140, No. 1A: A316 (1965). 